\title{
Urethral Cancer pN1 TNM Finding v7
}

National Cancer Institute

\section{Source}

National Cancer Institute. Urethral CancerpN1 TNM Finding v7. NCI Thesaurus. Code C89388.

Urethral cancer with metastasis in a singe lymph node $2 \mathrm{~cm}$ or less in greatest dimension. (from AJCC 7th Ed.) 